\title{
The Impact of Brand Name on Consumers, Case of Bosnia and Herzegovina
}

\author{
Agim Mamuti, PhD \\ Faculty of Business and Economics, \\ University of New York in Tirana \\ agim.mamuti@yahoo.com
}

\begin{abstract}
Brand name is important for every company and every product, because the more people know about one product the more it will be sold. This paper will deal with the brand management and its impact on the consumer's behavior and society in Bosnia and Herzegovina. A survey is conducted about the brand name products in domestic correspondents via the internet. The results of the survey will show how big the impact of brand name products on the society and market is, and what are their positive and negative sides. The data which is used is primary data and its source is a survey which had 76 respondents from different cities in Bosnia and Herzegovina. The primary focus groups were people between the ages of 20 to 35 , because the main focus of advertisements is on them. The collected data is numerical except of the demographic data. The Seven point Likert scale was used in order to get the agreements of correspondents over six variables and twenty eight questions. The collected data were analyzed through statistical formulas to get the most accurate results.
\end{abstract}

Keywords: Brand name, Products, Promotion, Profitability, Consumers

\section{INTRODUCTION}

The name of a brand is the fundamental indicator of the brand. The name of the brand is the basis for raising awareness of the brand and Communication efforts. Often even more important is the fact that it can generate association which serves to describe the brand. (Aaker, 1991)

The brand name is very significant choice because some time it captures the central theme or key association of a product in a very condensed and reasonable fashion. Brand names can be extremely successful means of communication. Some companies assign their product with a brand name that in reality has nothing to do with the emotional experience but is catchy and a name that people can easily memorize. The core base of naming a brand is that it should be unique can be easily differentiated from other names, easy to remember and are attractive to customers. (Keller, 2012)

\section{SURVEY ANALYSIS}

The data which is used is primary data and its source is a survey which had 76 respondents from different cities in Bosnia and Herzegovina. The primary focus groups were people between the ages of 20 to 35 . The collected data is numerical except of the demographic data. The Seven point Likert scale was used in order to get the agreements of correspondents over six variables and twenty eight questions. The collected data was analyzed through statistical formulas to get the most accurate results.

\subsection{Variables}

In this survey six main variables exist, which will help us to explain the brand name and the factors which can lead to the success of a brand or to its failure. 
Table 1: Variables

\begin{tabular}{|l|l|l|}
\hline No & Variable name & Explanation \\
\hline 1. & Consumer behavior & $\begin{array}{l}\text { The consumer behavior is a variable which can be with mathematical and } \\
\text { statically analysis predictable. The behavior of customers is an element which } \\
\text { is not much changeable, because people have their habits which they don't } \\
\text { like to change }\end{array}$ \\
\hline 2. & Brand name products & $\begin{array}{l}\text { This variable is especially important for customers because they identify } \\
\text { themselves with brand name products and many societies are created on the } \\
\text { fundament of the consumption of brand name products. }\end{array}$ \\
\hline 3. & $\begin{array}{l}\text { Brand name products } \\
\text { promotion }\end{array}$ & $\begin{array}{l}\text { This variable is constantly changing and the most expensive variable but the } \\
\text { one which brings the highest profit. Promotion is important for every brand no } \\
\text { matter how big it is. }\end{array}$ \\
\hline 5. & $\begin{array}{l}\text { Brand name products } \\
\text { impact on society }\end{array}$ & $\begin{array}{l}\text { Certain products can have deeply impacts on the society. Many of these } \\
\text { societies can only identify themselves when they consume a certain brand } \\
\text { name product. }\end{array}$ \\
\hline 6. & $\begin{array}{l}\text { Positive/Negative sides of } \\
\text { brand name products }\end{array}$ & $\begin{array}{l}\text { Every product has competition and is competition for other products. It is a } \\
\text { variable which appear in every market. In the best case there is a huge } \\
\text { competition in which the consumers can choose what to consume and at } \\
\text { which price. }\end{array}$ \\
\hline
\end{tabular}

Source: Author

\subsection{Analysis of the data - results}

Table 2: Socio-demographic data of respondents

\begin{tabular}{|l|l|l|l|}
\hline \multicolumn{2}{|l|}{ Socio-demographic data of respondents } \\
\hline Variables & Categories & Frequency & Percent \\
\hline \multirow{4}{*}{ Gender } & Male & 38 & $50.00 \%$ \\
\cline { 2 - 4 } & Female & 38 & $50.00 \%$ \\
\cline { 2 - 4 } & Total & 76 & $100.00 \%$ \\
\hline \multirow{5}{*}{ Age } & $18-25$ & 32 & $42.11 \%$ \\
\cline { 2 - 4 } & $26-30$ & 16 & $21.05 \%$ \\
\cline { 2 - 4 } & $31-40$ & 25 & $32.89 \%$ \\
\cline { 2 - 4 } & $41+$ & 3 & $3.95 \%$ \\
\cline { 2 - 4 } & Total & 76 & $100.00 \%$ \\
\hline \multirow{5}{*}{ Education } & Primary & 12 & $15.79 \%$ \\
\cline { 2 - 4 } & High School & 32 & $42.1 \%$ \\
\cline { 2 - 4 } & Bachelor & 26 & $34.21 \%$ \\
\cline { 2 - 4 } & Master & 5 & $1.32 \%$ \\
\cline { 2 - 4 } & PHD & 1 & \\
\hline
\end{tabular}




\begin{tabular}{|c|c|c|c|}
\hline & Total & 76 & $100.00 \%$ \\
\hline \multirow{7}{*}{ Personal Income } & $0-250$ & 2 & $2.63 \%$ \\
\hline & $251-400$ & 23 & $30.26 \%$ \\
\hline & $401-700$ & 28 & $36.84 \%$ \\
\hline & $701-900$ & 14 & $18.42 \%$ \\
\hline & $901-1200$ & 6 & $7.89 \%$ \\
\hline & $1201+$ & 3 & $3.95 \%$ \\
\hline & Total & 76 & $100.00 \%$ \\
\hline \multirow{4}{*}{ Household size } & $0-2$ members & 41 & $53.95 \%$ \\
\hline & 3-5 members & 31 & $40.79 \%$ \\
\hline & $5+$ members & 4 & $5.26 \%$ \\
\hline & Total & 76 & $100.00 \%$ \\
\hline \multirow{5}{*}{ Household Income } & $0-400$ & 2 & $2.63 \%$ \\
\hline & $400-800$ & 18 & $23.68 \%$ \\
\hline & $800-1200$ & 43 & $56.58 \%$ \\
\hline & $1200+$ & 13 & $17.11 \%$ \\
\hline & Total & 76 & $100.00 \%$ \\
\hline \multirow{5}{*}{$\begin{array}{l}\text { Household } \\
\text { expenses }\end{array}$} & $0-200$ & 16 & $21.05 \%$ \\
\hline & $200-400$ & 37 & $48.68 \%$ \\
\hline & $400-800$ & 13 & $17.11 \%$ \\
\hline & $800+$ & 10 & $13.16 \%$ \\
\hline & Total & 76 & $100.00 \%$ \\
\hline \multirow{3}{*}{ Residency } & House & 26 & $34.67 \%$ \\
\hline & Apartment & 49 & $65.33 \%$ \\
\hline & Total & 75 & $100.00 \%$ \\
\hline \multirow{5}{*}{ Working status } & Student & 37 & $49.33 \%$ \\
\hline & Unemployed & 16 & $21.33 \%$ \\
\hline & $\begin{array}{l}\text { Employed in public } \\
\text { sector }\end{array}$ & 10 & $13.33 \%$ \\
\hline & $\begin{array}{l}\text { Employed in private } \\
\text { sector }\end{array}$ & 12 & $16.00 \%$ \\
\hline & Total & 75 & $100.00 \%$ \\
\hline
\end{tabular}

Source: Author

The main categories of the respondents have been summarized in nine variables which will show that the results come from different people from different social structures, genders and wealth statuses. 
Table 3: Consumer Behavior

\begin{tabular}{|l|l|l|l|l|l|l|}
\hline $\begin{array}{l}\text { Item } \\
\text { number }\end{array}$ & Consume behavior & $\mathbf{N}$ & Mean & $\begin{array}{l}\text { Std. } \\
\text { Deviation }\end{array}$ & T-value & P-value \\
\hline 1 & You only buy products that you need & 76 & 5.658 & 1.090 & -0.21 & 0.84 \\
\hline 2 & You buy every time the same products & 76 & 6.039 & 1.038 & 0.11 & 0.91 \\
\hline 3 & $\begin{array}{l}\text { When you buy something, you buy it } \\
\text { because of the quality }\end{array}$ & 76 & 2.697 & 0.980 & 0.12 & 0.91 \\
\hline 4 & $\begin{array}{l}\text { When you buy something, you buy it } \\
\text { because of the price }\end{array}$ & 76 & 4.026 & 0.993 & 0.00 & 1.00 \\
\hline 5 & $\begin{array}{l}\text { When you buy something, you buy it } \\
\text { because of the brand name }\end{array}$ & 76 & 2.526 & 1.039 & 1.11 & 0.27 \\
\hline 6 & $\begin{array}{l}\text { Your buying decision in affected by brand } \\
\text { name products }\end{array}$ & 76 & 3.132 & 0.998 & 0.00 & 1.00 \\
\hline
\end{tabular}

Source: Author

The consumer variable analysis shows that people buy products because they are accustomed to buy the same products from their childhood $(M=6.039)$. Another point which is concluded through this variable analysis is that domestic people don't buy many products because of their brand name. In B\&H people live in a society which hasn't much money and they pay more attention on the price than on the brand name.

Table 4: Brand name products

\begin{tabular}{|l|l|l|l|l|l|l|}
\hline $\begin{array}{l}\text { Item } \\
\text { number }\end{array}$ & Brand name products & $\mathbf{N}$ & Mean & $\begin{array}{l}\text { Std. } \\
\text { Deviation }\end{array}$ & T-value & P-value \\
\hline 1 & $\begin{array}{l}\text { Brand name products are qualitatively } \\
\text { better than no name products }\end{array}$ & 76 & 2.908 & 0.982 & 0.35 & 0.73 \\
\hline 2 & $\begin{array}{l}\text { Brand name products are cheaper than no } \\
\text { name products }\end{array}$ & 76 & 1.974 & 1.019 & -1.59 & 0.12 \\
\hline 3 & $\begin{array}{l}\text { Brand name products are healthier than } \\
\text { no name products }\end{array}$ & 76 & 1.908 & 1.022 & 0.33 & 0.74 \\
\hline 4 & $\begin{array}{l}\text { Brand name products are easier } \\
\text { accessible than no name products }\end{array}$ & 76 & 4.566 & 0.984 & -0.81 & 0.42 \\
\hline 5 & $\begin{array}{l}\text { Because of their quality, brand name } \\
\text { products have loyal customers }\end{array}$ & 76 & 5.658 & 1.001 & 2.11 & 0.40 \\
\hline
\end{tabular}

\section{Source: Author}

The result of this analysis shows that the biggest advantage of brand name products is those brand name products have their customers which are loyal to the brand because of some reasons $(M=5.658)$. Maybe it is because of the quality or the tradition or some other reason. Another result show that people are not satisfied with the healthiness of brand name products, because more attention is given to the promotion of the products than on its affects on the human health $(\mathrm{M}=1.908)$. 
Table 5: Brand name products promotion

\begin{tabular}{|l|l|l|l|l|l|l|}
\hline $\begin{array}{l}\text { Item } \\
\text { number }\end{array}$ & Brand name products promotion & $\mathbf{N}$ & Mean & $\begin{array}{l}\text { Std. } \\
\text { Deviation }\end{array}$ & T-value & P-value \\
\hline 1 & $\begin{array}{l}\text { Brand name products have better } \\
\text { promotion than no name products }\end{array}$ & 76 & 3.632 & 0.991 & 0.23 & 0.82 \\
\hline 2 & $\begin{array}{l}\text { Brand name products got their promotion } \\
\text { with the help of celebrities }\end{array}$ & 76 & 4.868 & 1.024 & 0.89 & 0.37 \\
\hline 3 & $\begin{array}{l}\text { Brand name products invest over 50\% of } \\
\text { their revenue into promotions }\end{array}$ & 76 & 3.658 & 0.960 & -0.71 & 0.48 \\
\hline 4 & $\begin{array}{l}\text { They are so good sold only because of } \\
\text { their promotion }\end{array}$ & 76 & 3.855 & 0.989 & -0.12 & 0.91 \\
\hline
\end{tabular}

Source: Author

Promotion is the main element in the marketing segment. Without promotion no product would be known and when customers would come into a store they would buy just the first product they see. The promotion with the help of celebrities seems to be the easiest way to promote the brand/product and the celebrity at the same time $(M=4.868)$. Another point that the respondents identify is that producers invest much more than $50 \%$ of their revenues on promotion but calculating their revenues from the new sale after the promotion are significantly higher $(M=3.658)$.

Table 6: Brand name products impact on society

\begin{tabular}{|l|l|l|l|l|l|l|}
\hline $\begin{array}{l}\text { Item } \\
\text { number }\end{array}$ & Brand name products impact on society & $\mathbf{N}$ & Mean & $\begin{array}{l}\text { Std. } \\
\text { Deviation }\end{array}$ & T-value & P-value \\
\hline 1 & $\begin{array}{l}\text { Brand name products determine what a } \\
\text { society will do and on what they will spend } \\
\text { their money }\end{array}$ & 76 & 4.197 & 0.994 & 0.11 & 0.91 \\
\hline 2 & $\begin{array}{l}\text { Brand name products and their promotions } \\
\text { are set only to acquire maximum profit }\end{array}$ & 76 & 6.224 & 0.988 & -1.52 & 0.13 \\
\hline 3 & $\begin{array}{l}\text { Kids focus their live around brand products } \\
\text { and their lifestyle is directed by brand name } \\
\text { products producers }\end{array}$ & 76 & 5.434 & 1.087 & -1.38 & 0.17 \\
\hline 4 & $\begin{array}{l}\text { The life standards are oriented toward } \\
\text { brand name products }\end{array}$ & 76 & 3.184 & 1.055 & 0.65 & 0.52 \\
\hline 5 & $\begin{array}{l}\text { The society creates classes according to } \\
\text { the consumption of brand name products }\end{array}$ & 76 & 5.789 & 1.011 & 1.14 & 0.26 \\
\hline
\end{tabular}

Source: Author

Everything can affect the society but brand name products can set the standards for some societies. The correspondents agree that the brand name product promotions are created only to maximize profits but not to help the customers to get better and healthier products ( $M=6.224)$. In countries in which exists many societies and in which the life standard is better, the people there can orient their life standards on the basis of some brand name products, but in B\&H that is not the case because here people trust the local products more than the brand name products $(M=3.184)$. 
Table 7: Competitiveness

\begin{tabular}{|l|l|l|l|l|l|l|}
\hline $\begin{array}{l}\text { Item } \\
\text { number }\end{array}$ & Competitiveness & $\mathbf{N}$ & Mean & $\begin{array}{l}\text { Std. } \\
\text { Deviation }\end{array}$ & T-value & P-value \\
\hline 1 & $\begin{array}{l}\text { Brand name product producers pay more } \\
\text { attention on the promotion of their product } \\
\text { than on its quality }\end{array}$ & 76 & 2.250 & 1.060 & 0.76 & 0.45 \\
\hline 2 & $\begin{array}{l}\text { The producers set lower prices in } \\
\text { accordance to eliminate no name products }\end{array}$ & 76 & 4.539 & 0.999 & 1.50 & 0.14 \\
\hline 3 & $\begin{array}{l}\text { Brand name products are available at almost } \\
\text { every store }\end{array}$ & 76 & 5.118 & 1.032 & -3.73 & 0.00 \\
\hline 4 & $\begin{array}{l}\text { The fight between two or more brand name } \\
\text { products often causes that no name } \\
\text { products disappear from the market }\end{array}$ & 76 & 3.355 & 1.003 & -0.34 & 0.73 \\
\hline
\end{tabular}

Source: Author

In every market exist competitors which fight against each other in order to get the most customers to realize the maximum profit. The survey data has shown that the advantage of brand name products in the competition fight against other products is their availability at almost every store $(M=5.118)$. Another important point which can be concluded is that producers of brand name products have enough funds to drop the prices to the minimum in accordance to eliminate the competition so that only them can survive on the market $(M=4.539)$.

Table 8: Positive/Negative sides of brand name products

\begin{tabular}{|l|l|l|l|l|l|l|}
\hline $\begin{array}{l}\text { Item } \\
\text { number }\end{array}$ & $\begin{array}{l}\text { Positive/Negative sides of brand name } \\
\text { products }\end{array}$ & $\mathbf{N}$ & Mean & $\begin{array}{l}\text { Std. } \\
\text { Deviation }\end{array}$ & T-value & P-value \\
\hline 1 & Its quality & 76 & 4.776 & 0.988 & -0.81 & 0.42 \\
\hline 2 & Its price & 76 & 4.395 & 1.034 & -0.22 & 0.83 \\
\hline 3 & Its impact on the society & 76 & 2.908 & 1.098 & -0.73 & 0.47 \\
\hline 4 & Its accessibility on the market & 76 & 5.171 & 1.063 & 0.54 & 0.59 \\
\hline
\end{tabular}

Source: Author

Brand name products have their positive sides like their quality and their accessibility, but they have also negative sides like their price and their impact on the society. The price is high because of the high promotion costs and that is not good for the customers which don't have enough funds, but which want qualitatively good products. The availability is good because the higher the distribution of the product, the higher the chances that customers will buy their product.

\subsection{Discussion}

Table 9: Overall Variables

\begin{tabular}{ll} 
Measures & Mean \\
\hline Consume behavior & 4.013 \\
Brand name products & 3.403
\end{tabular}




$\begin{array}{ll}\text { Brand name products promotion } & 4.003 \\ \begin{array}{l}\text { Brand name products impact on } \\ \text { society }\end{array} & 4.966 \\ \begin{array}{l}\text { Competitiveness } \\ \text { Positive/Negative sides of brand }\end{array} & 3.816 \\ \text { name products } & 4.313 \\ \text { Total } & 4.086\end{array}$

\section{Source: Author}

The sum of all variables shows what the main points about brand name products need to be discussed. The brand name products have the biggest impact on the society, because as we can see in the modern era everything is labeled and people are criticized on the basis of their buying behavior. If they are not buying brand name products they are not an accepted part of the society. Another point which needs to be mentioned is that customers pay much more attention to brand name products than on no name products which might have, in many cases, better prices and better quality than brand name products.

\section{CONCLUSION}

The following conclusions could be drawn from the results of this survey:

Brand names have a global impact on the society and the behavior of individuals insides of the society;

It defines what to buy, where to buy it and what is socially acceptable to buy;

Brand name products affect the consumer behavior by giving him the illusion that only this brand name product is qualitatively good and that they need to buy it at any cost in order to be satisfied.

If there were a simple formula or a fixed calculation, companies could also calculate the brand value for them and would not need the assistance of accountants and brand consulting.

Today, we can also be interested in controllers and CFOs for brands, because it is generally accepted that brand management is an essential part of business success. Therefore, the marketing needs a new language to describe itself and its services better. On one hand it helps the orientation on brand equity brand management to develop better and more effective strategy if it is charged not only monetarily, but also with behavioral science. On the other hand, a good argument structure and the interplay between brand management objectives and the brand value can also CFOs convict of a higher marketing budget through.

\section{REFERENCES:}

[1] Aaker A David, Managing Brand Equity, Capitalizing on the Value of a Brand Name, New York Free Press (1991), p.187

[2] Aaker \& McLoughlin 2010; Strategic Market Management: Global Perspectives; (Publisher: Wiley); p. 179-203

[3] Aaker 2004; Brand Portfolio Strategy: Creating Relevance, Differentiation, Energy, Leverage, and Clarity; (Publisher: Free Press); p. 201-219

[4] Chevalier \& Mazzalovo 2012; Luxury Brand Management: A World of Privilege; (Publisher: Wiley); p. 120-148

[5] Davis 2000; Brand Asset Management: Driving Profitable Growth Through Your Brands; (Publisher: Jossey-Bass); p. $145-158$

[6] Haines 2011; Managing Product Management: Empowering Your Organization to Produce Competitive Products and Brands; (Publisher: McGraw-Hill); p. 175-192 
[7] Heding, Knudtzen, Bjerre 2008; Brand Management: Research, Theory and Practice; (Publisher: Routledge); p. 6274

[8] Johansson \& Carlson 2014; Contemporary Brand Management; (Publisher: SAGE Publications); p. 13-30

[9] Kapferer 2004; The New Strategic Brand Management: Creating and Sustaining Brand Equity Long Term (New Strategic Brand Management: Creating \& Sustaining Brand Equity); (Publisher: Kogan Page Business Books); p. 473-499

[10] Keller 2012; Strategic Brand Management: Building, Measuring, and Managing Brand Equity; (Publisher: Prentice Hall); p. 98-120

[11] Keller, Aperia \& Georgson 2013; Strategic Brand Management; (Publisher: Prentice Hall); p. 459-483

[12] Laidler-Kylander \& Stenzel 2013; The Brand IDEA: Managing Nonprofit Brands with Integrity, Democracy and Affinity; (Publisher: Jossey-Bass); p. 10-27

[13] Malone \& Fiske 2013; The Human Brand: How We Relate to People, Products, and Companies; (Publisher: JosseyBass); p. 37-57

[14] Powell \& Baker 2013; Management Science: The Art of Modeling with Spreadsheets; (Publisher: Wiley); p. 430-457

[15] Rosenbaum-Elliott, Percy \& Pervan 2011; Strategic Brand Management; (Publisher: Oxford University Press); p. 5369

[16] Temporal 2010; Advanced Brand Management: Managing Brands in a Changing World; (Publisher: Wiley); p. 70-91

[17] Wheeler 2012, Designing Brand Identity: An Essential Guide for the Whole Branding Team; (Publisher: Wiley); p. 205-224

\section{APPENDIX}

\section{The Survey Questionnaire}

\section{STRATEGIC SUCCESS FACTORS OF BRAND MANAGEMENT AND ITS IMPACT ON THE BRAND VALUE}

\section{Please answer all questions}

For each numeric question, circle the number that best reflects your opinion of the factor judged $1=$ strongly disagree, 2=disagree, $3=$ =slightly disagree, 4=neither, $5=$ slightly agree, $6=$ =agree, $7=$ strongly agree

Circle only one number for each scale

\begin{tabular}{|c|c|}
\hline \multicolumn{2}{|c|}{ Demographics } \\
\hline a & Your department/unit: \\
\hline b & Your current position/role in dept/unit: \\
\hline c & How long have you been in current position/role? \\
\hline d & Your highest education level: $\quad$ Primary High School Bachelor Master PHD \\
\hline e & Gender: $\quad$ Male $\quad$ Female \\
\hline f & Age: $\quad 18-25 \quad 26-30 \quad 31-40 \quad 41 \leq$ \\
\hline
\end{tabular}




\begin{tabular}{|l|l|lllllll|}
\hline \multicolumn{2}{|l|}{ Please indicate your level of agreement about the following: Consume behavior } & Disagree & \multicolumn{2}{c|}{ Agree } \\
\hline a & You only buy products that you need & 1 & 2 & 3 & 4 & 5 & 6 & 7 \\
\hline b & You buy every time the same products & 1 & 2 & 3 & 4 & 5 & 6 & 7 \\
\hline b & When you buy something, you buy it because of the quality & 1 & 2 & 3 & 4 & 5 & 6 & 7 \\
\hline c & When you buy something, you buy it because of the price & 1 & 2 & 3 & 4 & 5 & 6 & 7 \\
\hline d & When you buy something, you buy it because of the brand name & 1 & 2 & 3 & 4 & 5 & 6 & 7 \\
\hline e & Your buying decision in affected by brand name products & 1 & 2 & 3 & 4 & 5 & 6 & 7 \\
\hline
\end{tabular}

\begin{tabular}{|l|l|llllllll|}
\hline \multicolumn{3}{|l|}{ Please indicate your level of agreement about the following: Brand name products } & Disagree $\quad$ Agree \\
\hline a & Brand name products are qualitatively better than no name products & 1 & 2 & 3 & 4 & 5 & 6 & 7 \\
\hline b & Brand name products are cheaper than no name products & 1 & 2 & 3 & 4 & 5 & 6 & 7 \\
\hline c & Brand name products are healthier than no name products & 1 & 2 & 3 & 4 & 5 & 6 & 7 \\
\hline d & Brand name products are easier accessible than no name products & 1 & 2 & 3 & 4 & 5 & 6 & 7 \\
\hline e & Because of their quality, brand name products have loyal customers & 1 & 2 & 3 & 4 & 5 & 6 & 7 \\
\hline
\end{tabular}

\begin{tabular}{|c|c|c|}
\hline \multicolumn{2}{|r|}{$\begin{array}{l}\text { Please indicate your level of agreement about the following: Brand name products } \\
\text { promotion }\end{array}$} & \multirow{2}{*}{\begin{tabular}{llllllll} 
Disagree & & \multicolumn{3}{c}{ Agree } \\
1 & 2 & 3 & 4 & 5 & 6 & 7
\end{tabular}} \\
\hline a & Brand name products have better promotion than no name products & \\
\hline b & Brand name products got their promotion with the help of celebrities & $\begin{array}{lllllll}1 & 2 & 3 & 4 & 5 & 6 & 7\end{array}$ \\
\hline c & Brand name products invest over $50 \%$ of their revenue into promotions & $\begin{array}{lllllll}1 & 2 & 3 & 4 & 5 & 6 & 7\end{array}$ \\
\hline d & They are so good sold only because of their promotion & $\begin{array}{lllllll}1 & 2 & 3 & 4 & 5 & 6 & 7\end{array}$ \\
\hline
\end{tabular}

\begin{tabular}{|c|c|c|}
\hline \multicolumn{2}{|r|}{$\begin{array}{l}\text { Please indicate your level of agreement about the following: Brand name products } \\
\text { impact on society }\end{array}$} & \multirow{2}{*}{$\begin{array}{llllllll}\text { Disagree } & & \text { Agree } \\
1 & 2 & 3 & 4 & 5 & 6 & 7\end{array}$} \\
\hline a & $\begin{array}{l}\text { Brand name products determine what a society will do and on what they will spend } \\
\text { their money }\end{array}$ & \\
\hline b & Brand name products and their promotions are set only to acquire maximum profit & 122334567 \\
\hline c & $\begin{array}{l}\text { Kids focus their live around brand products and their lifestyle is directed by brand } \\
\text { name products producers }\end{array}$ & $\begin{array}{lllllll}1 & 2 & 3 & 4 & 6 & 7\end{array}$ \\
\hline d & The life standards are oriented toward brand name products & 122334567 \\
\hline e & The society creates classes according to the consumption of brand name products & 122344566 \\
\hline
\end{tabular}

